\title{
Aktualne tendencje w polityce kryminalnej wobec przestępczości podatkowej
}

\section{The current trends in criminal policy towards tax crime}

ABSTRAKT: Reakcja ustawodawcy na przestępczość podatkową odzwierciedla tendencje obserwowane w całej karnistyce, wynikające z poglądu, według którego przestępstwo stanowi dowód na wadliwie skonstruowane prawo, czego rezultatem jest narastająca niestabilność, kazuistyka $\mathrm{i}$ inflacja prawa $\mathrm{z}$ tendencją do rozszerzania zakresu kryminalizacji i zaostrzania penalizacji.

W obszarze przestępczości podatkowej zjawisko to występuje pod hasłem „uszczelniania systemu podatkowego".

Ustawodawca, wypowiadając wojnę zwłaszcza oszustwom VAT, nie zaostrzył jednak kar za same te oszustwa, ale za zachowania znajdujące się "na przedpolu” oszustw, polegające na wystawianiu i obrocie nierzetelnymi fakturami oraz rachunkami. Przejawem tego jest w obrębie kodeksu karnego skarbowego drastyczne zaostrzenie w 2016 r. represji karnej za wystawianie i obrót nierzetelnymi fakturami oraz rachunkami, natomiast w obrębie kodeksu karnego - wprowadzenie kwalifikowanych typów fałszerstw dokumentów, których przedmiotem są faktury.

Kolejnym przejawem omawianych tendencji był projekt obszernej nowelizacji kodeksu karnego skarbowego z grudnia 2018 r., którego istota sprowadzała się do dalszego rozszerzania zakresu kryminalizacji, zaostrzania penalizacji oraz wypaczenia ukształtowanej dotychczas racjonalnie zasady priorytetu egzekucji danin publicznych przed represją.

Projekt ten jednak nie wszedł w życie, a zamiast tego ustawodawca od dwóch lat konsekwentnie cząstkowymi nowelizacjami rozszerza zakres kryminalizacji, obejmując nią zwłaszcza przypadki niedopełnienia lub niewłaściwego wykonania rozbudowanych obowiązków informacyjnych.

Oprócz oszustw podatkowych zjawiskiem, które niepokoi organy fiskalne i ustawodawców wielu państw, jest tzw. agresywna optymalizacja podatkowa, w ramach której określone czynności, np. rozporządzanie majątkiem czy przekształcenia struktur gospodarczych, służą wyłącznie lub przede wszystkim redukcji obciążeń podatkowych. Kryminalizacja sięga zaledwie na dalekie „przedpola” tego zjawiska i polega na obwarowaniu sankcjami karnymi niedopełnienia lub niewłaściwego wypełnienia obowiązków raportowania tzw. schematów podatkowych, co ma 
w założeniu umożliwiać organom fiskalnym wczesną identyfikację tych zachowań podatników, które stanowią przejawy agresywnej optymalizacji podatkowej, i zastosowanie przeciwko nim instrumentów podatkowoprawnych służących zwalczaniu tego zjawiska.

SŁOWA KLUCZE: prawo karne skarbowe, uszczelnianie systemu podatkowego, oszustwa VAT-owskie, agresywna optymalizacja podatkowa

ABSTRACT: Legislative response to tax crime reflects the trends that are observed throughout criminal law resulting from theory to which, a crime is an evidence of a defectively constructed law, the result of which is increasing instability, casuistry and regulatory drift with tendency to extend of scope criminalization and aggravating penalties.

In the field of tax crime, it is called "closing tax loophole".

The legislator, by declarating war on tax frauds, didn't increase penalties for tax frauds, however, legislator increased penalties for unreliable invoice and bills trading. Within the Fiscal Penal Code, this is reflected by tightening of a provisions concerning the unreliable invoice and bills trading, while within the Criminal Code - introducing a aggravated types of documents forgery which have their subject invoices.

The draft amendment of the Fiscal Penal Code (December 2018) was another manifestation of discussed tendencies. Its essence came down to further extend of scope criminalization, aggravating penalties and distortion of priority of principle for enforcement to public levies.

However, this draft didn't enter into force, instead, for two years - the legislator, by means of amendments, consequently, extends the scope of criminalization, extending it to the cases of failure or improper performance of information obligations.

Apart from tax frauds, what concerns to tax authorities and legislators of several countries, is the so-called "aggressive tax optimization", in which certain activities, e.g., asset disposal or social structure transformation, are undertaken solely or primarily - tax burden reductions. Its criminalization extends to the far "frontiers" and leads to imposition of criminal penalties for failure or improper fulfillment of reporting obligations the so-called "tax scheme", which is intended to allow, to tax authorities - an early identification of taxpayer's behaviours that are reflected by aggressive tax optimization.

KEYWORDS: penal fiscal law, closing tax loophole, fraud tax, aggressive tax optimization

\section{Wstęp}

Określenie „aktualne tendencje” potocznie wskazuje na czas teraźniejszy. Jednak polityka kryminalna jest pewnym procesem, z którego trudno wyjąć jakiś krótki odcinek czasowy i analizować go w oderwaniu od szerszego tła czasowego. Dopiero rozleglejsza perspektywa pozwala stwierdzić, czy mamy do czynienia z kontynuacją, czy ze zmianą polityki. Niedawno minione dwudziestolecie obowiązywania kodeksu karnego skarbowego jest okazją do przedstawienia jego ewolucji, oczywiście ze szczególnym uwzględnieniem najnowszych tendencji. Ponieważ zaś przestępczość zwana umownie "podatkową" zdecydowanie dominuje wśród czterech kategorii rodzajowych przestępstw i wykroczeń skarbowych, zarówno pod względem systematyki ustawowej, jak i obszerności 
rozdziału, wysokości sankcji, a także w statystykach i - co się z tym wiąże - gdy chodzi o zagrożenia dla bezpieczeństwa ekonomicznego państwa, ta właśnie kategoria przestępczości będzie przedmiotem niniejszego opracowania.

\section{Kwestie terminologiczne}

Uczono mnie, że jeżeli w tytule opracowania naukowego posługujemy się określeniami niejednoznacznymi, rodzącymi wątpliwości co do swego zakresu, to należy - najlepiej na wstępie - wyjaśnić sposób ich rozumienia, czyli zdefiniować na potrzeby danej pracy.

Trzymając się tej wytycznej, rozpocznę od wskazania na dwa określenia zawarte w tytule tego artykułu, mianowicie: „polityka kryminalna” (to pojęcie widnieje również w tytule czasopisma) oraz „przestępczość podatkowa”. Oba te sformułowania używane są de facto dość intuicyjnie i funkcjonują jako pewne umowne skróty myślowe.

Pierwsze z tych określeń (polityka kryminalna) jest w karnistyce powszechnie używane, ale niejednoznacznie definiowane bądź pozostawiane bez bliższego objaśnienia nawet wówczas, gdy tytuły opracowań głoszą, że ich przedmiotem będzie np. rola takich to a takich środków w „polityce kryminalnej”'. Bywa również, że sformułowanie „polityka kryminalna” traktowane jest zamiennie z określeniem „polityka karna” 2 . Niektórzy z kolei uważają, że polityka karna jest częścią polityki kryminalnej ${ }^{3}$. Elementami konstytuującymi te pojęcia są: określona działalność i jej zakres, cele tej działalności oraz podmioty realizujące tę działalność ${ }^{4}$. Różnice w ujęciu tych elementów wpływają ostatecznie na różne sposoby definiowania terminów: „polityka kryminalna” oraz „polityka karna”. Niektórzy pojmują politykę kryminalną jako działalność polityczną, inni - jako naukę, przy czym umiejscowienie polityki kryminalnej w systemie nauk napotyka trudności związane zwłaszcza z wątpliwościami co do jej samoistnego charakteru naukowego ${ }^{5}$.

Szersze rozwinięcie tej kwestii definicyjnej wymagałoby jej analizy w pracach tych autorów, którzy obszernie zajmowali się tą problematyką. Jednak dla

${ }^{1}$ Nie wskażę tu jednak żadnego konkretnego opracowania, albowiem po pierwsze, nie czuję się uprawniony, po drugie, nie chcę czynić żadnych przytyków moim koleżankom i kolegom penalistom, wreszcie - w tej pracy nie byłoby to w ogóle potrzebne.

2 Zob. T. Szymanowski, w: System Prawa Karnego, t. 1, Zagadnienia ogólne, red. A. Marek, C.H.Beck, Warszawa 2010, s. 210.

3 Np. L. Lernell, Współczesne zagadnienia polityki kryminalnej. Problemykryminogenne ipenologiczne, Wydawnictwo Prawnicze, Warszawa 1978, s. 24.

4 T. Szymanowski, w: System Prawa Karnego..., s. 212-213.

5 Zob. L. Tyszkiewicz, Kryminologia, Wydawnictwo Uniwersytetu Śląskiego, Katowice 1983, s. 50 . 
potrzeb niniejszego opracowania nie jest to potrzebne. Przyjmuję zatem stanowisko reprezentowane przez wybitnego przedstawiciela nauki, zarówno prawa karnego, jak i kryminologii - Leona Tyszkiewicza, wyrażone również w aktualnym podręczniku akademickim do nauki prawa karnego, którego jestem jednym ze współautorów ${ }^{6}$. W tym ujęciu zasadniczy trzon polityki kryminalnej, która stanowi swoisty „pomost” między kryminologią a prawem karnym, dzieli się na dwie sfery: politykę kryminalizacyjną i politykę penalizacyjną. Pierwsza odpowiada na pytanie - za co karać, druga - jak karać. Natomiast polityka karna jest w tym rozumieniu praktyką stosowania przez sądy środków penalnych.

$\mathrm{Na}$ podstawie tego ujęcia dla potrzeb niniejszej pracy rozumiał będę politykę kryminalną jako działalność legislacyjną w zakresie kryminalizacji, czyli tworzenia katalogu czynów zabronionych, oraz w zakresie penalizacji, czyli sposobu reakcji na te zachowania.

Przedmiotem tego opracowania jest polityka kryminalna, a ściślej - aktualne jej tendencje w odniesieniu do przestępczości podatkowej. To ostatnie określenie rodzi oczywiste skojarzenia $\mathrm{z}$ zachowaniami karalnymi ze względu na ich szkodliwość dla funkcjonowania systemu podatkowego, określonymi - gdy chodzi o ich kwalifikację prawną - w rozdziale 6 Działu II w Tytule I kodeksu karnego skarbowego: Przestepstwa skarbowe $i$ wykroczenia skarbowe przeciwko obowiazkom podatkowym i rozliczeniom $z$ tytulu dotacji lub subwencji. To skojarzenie co do zasady jest poprawne, jednak wymaga ono pewnego uzupełnienia. $\mathrm{W}$ istocie bowiem w ramach tego, co umownie nazywamy "przestępczością podatkową", można wyodrębnić dwie kategorie: przestępczość rzeczywiście „podatkową" (sensu stricto) oraz przestępczość pozornie „podatkową”, a w istocie „kryminalną"”. Widać to szczególnie wyraźnie na przykładzie tzw. przestępczości „VAT-owskiej”, czyli związanej z podatkiem od towarów i usług (VAT). Istnieją dwa mechanizmy oszustw w zakresie tego podatku. Pierwszy $\mathrm{z}$ nich polega na pozorowaniu poprzez niezgodną z rzeczywistością dokumentację korzystnych dla sprawców różnic kwot między podatkiem naliczonym a należnym, wynikającym ze zdarzeń (transakcji), które w rzeczywistości miały miejsce. Drugi zaś mechanizm polega na pozorowaniu samych transakcji jako zdarzeń będących rzekomo źródłem zobowiązania podatkowego w podatku VAT i uruchamianiu $\mathrm{w}$ ten sposób bez faktycznych i prawnych ku temu podstaw procedury podatkowej VAT, a w jej efekcie - wyłudzaniu od Skarbu Państwa znacznych kwot tytu-

${ }^{6}$ Prawo karne. Część ogólna, szczególna i wojskowa, red. T. Dukiet-Nagórska, O. Sitarz, Wolters Kluwer, Warszawa 2020, s. 37; zob. też L. Tyszkiewicz, Od naturalizmu do humanizmu w kryminologii, Wydawnictwo Uniwersytetu Śląskiego, Katowice 1992, s. 131.

7 Zob. L. Wilk, „Kryminalne” aspekty przestępczości podatkowej, „Archiwum Kryminologii” 2009, t. 31, s. 212 i nast. Proszę pominąć okoliczność, że określenie "przestępstwo kryminalne” jest oczywistym pleonazmem, biorąc pod uwagę etymologię słowa „kryminalny” - od crimen 'przestępstwo'. 
łem rzekomego zwrotu podatku ${ }^{8}$. Nie ulega wątpliwości, że pierwszy mechanizm podpada pod stosowne przepisy kodeksu karnego skarbowego jako przestępstwo (lub wykroczenie) skarbowe. Natomiast $\mathrm{w}$ drugim obowiązek podatkowy jest fingowany - nawet jeżeli jakiś przedmiot „transakcji” fizycznie istnieje (nie tylko „na papierze”, czyli w fakturze VAT), to nie ma on żadnego praktycznie realnego znaczenia gospodarczego i handlowego, i służy wyłącznie uruchomieniu przepływu funduszy przez konta kolejnych „kontrahentów” w celu wyłudzania zwrotu podatku VAT. U wystawcy faktury „pustej” (fikcyjnej) nie powstaje w rzeczywistości obowiązek podatkowy, gdyż nie ma tutaj w istocie przedmiotu i podstawy opodatkowania, kwota zaś wykazana na „pustej” fakturze jako rzekomy „podatek” faktycznie nie jest podatkiem, lecz kwotą podszywającą się pod podatek $\mathrm{w}$ celu jej wyłudzenia. W takich sytuacjach działanie sprawcy mimo wykorzystania $\mathrm{w}$ nim procedury podatku VAT nie znajduje się $\mathrm{w}$ polu kryminalizacji kodeksu karnego skarbowego, nie powstała bowiem „podatkowa należność publicznoprawna", o której mowa w art. 76 k.k.s., albowiem w rzeczywistości nie było zdarzenia stanowiącego podstawę jej powstania. Takie działania, w związku z którymi nastąpiło uruchomienie procedur podatkowych w innych niż podatkowe celach, znajdują się w obszarze kryminalizacji kodeksu karnego jako oszustwo z art. 286, czy wcześniej - fałszerstwo intelektualne dokumentu w postaci faktury ${ }^{9}$.

W świetle powyższego widać, że rozróżnienie przestępczości „podatkowej” i „kryminalnej” ma tutaj charakter względny. Wszystko zależy od celu, w jakim określone podmioty występują $\mathrm{w}$ podatkowych procedurach. Jeżeli ma to związek z rzeczywistym obrotem gospodarczym lub cywilnoprawnym, to towarzyszące mu przestępstwo prowadzące do uszczuplenia podatku ma charakter „podatkowy” (skarbowy), natomiast gdy sam obrót jest fingowany wyłącznie w celu wykorzystania procedur i mechanizmów prawa podatkowego do wyłudzania mienia od organów skarbowych, to mamy do czynienia z przestępstwami o charakterze „kryminalnym” (powszechnymi).

Omawiając zatem kryminalnopolityczne podejście ustawodawcy do tak szeroko rozumianej „przestępczości podatkowej”, należy mieć na względzie zarówno regulacje prawa karnego skarbowego, jak i powszechnego.

${ }^{8}$ Ibidem, zob. także L. Wilk, Szczególne cechy odpowiedzialności za przestępstwa i wykroczenia podatkowe, Wydawnictwo Uniwersytetu Śląskiego, Katowice 2006, s. 455-456; Idem, Kwalifikacje prawne przestępstw skarbowych $i$ wykroczeń skarbowych związanych $z$ obrotem fakturami i rachunkami, w: Problematyka obrotu fakturami wystawionymi w sposób nierzetelny. Zagadnienia prawa karnego materialnego i procesowego, red. S. Kowalski, H. Paluszkiewicz, O. Włodkowski, C.H.Beck, Warszawa 2019, s. 26 i nast.

9 Zob. L. Wilk, Kwalifikacje prawne..., s. 26-30, z orzecznictwa zob. np. postanowienie SN z 1 marca 2004 V KK 248/03 Legalis, postanowienie SN z 10 lipca 2013 II KK 20/13 Legalis. 


\section{Ogólna charakterystyka obecnej polskiej polityki kryminalnej}

Ogólną cechą polskiej polityki kryminalnej - i obszar przestępczości podatkowej nie stanowi tu wyjątku - jest to, że jej rezultatem jest narastająca niestabilność ustawodawstwa karnego, w tym także karnoskarbowego. To zresztą cecha całego polskiego prawa, które uchwalane jest coraz szybciej i w coraz większej ilości. W Polsce zmienia się przepisy prawne najczęściej ze wszystkich krajów Unii Europejskiej. Przykładowo w 2016 r. weszło w życie 31906 stron tekstu nowelizacji prawa. Obrazowo rzecz ujmując - zadrukowane dwustronnie teksty nowelizujące układane kartka po kartce osiągają wysokość prawie 2 metrów (!), a zakładając przeczytanie jednej strony tekstu prawnego w 2 minuty, samo zaznajomienie się z treścią nowelizacji zawartych $\mathrm{w}$ „Dzienniku Ustaw” zajmowałoby kilka godzin dziennie każdego dnia roboczego (przy czym samo przeczytanie tekstu nowelizacji bez tekstu źródłowego nie ma przecież większego sensu ${ }^{10}$.

Zjawisko to nie omija prawa karnego. Wprawdzie stabilizacji normatywnej w obszarze prawa karnego nie można uznawać za wartość absolutną, samą w sobie, tym niemniej narastająca lawina nowelizacji, w tym nawet „nowelizacji do nowelizacji”, czyli nowelizacji do zmian już uchwalonych przed ich wejściem w życie, budzi coraz większe zaniepokojenie i zakłopotanie wśród karnistów. Twierdzą oni, że jest to wynik zmagań tendencji zwanej populizmem penalnym $\mathrm{z}$ tendencją zwaną racjonalizmem, w których to zmaganiach ewidentną przewagę zyskuje ten pierwszy kierunek ${ }^{11}$. Mówiąc najogólniej, racjonalizm penalny odwołuje się do kategorii obiektywnych, bada celowość kryminalizacji w perspektywie możliwego oddziaływania stosowania sankcji karnych na rzeczywisty stan przestępczości i dokonuje bilansu indywidualnych oraz społecznych zysków i strat, także tych, które mogą wystąpić w dłuższej perspektywie czasowej. Dla racjonalizmu penalnego charakterystyczne jest traktowanie prawa karnego w kategoriach ultima ratio i respektowanie zasad o charakterze gwarancyjnym. Motywem zmian legislacyjnych odwołujących się do paradygmatu racjonalizmu penalnego jest dążenie do spójności wewnątrzsystemowej oraz wstrzemięźliwość w rozszerzaniu zakresu kryminalizacji i zwiększaniu surowości penalizacji12.

Od tak scharakteryzowanej krótko ideologii racjonalizmu penalnego populizm penalny odróżnia się treścią swoich celów, które koncentrują się wokół zarządzania emocjami i postawami społecznymi, a stanowienie i stosowanie

${ }_{10}$ M. Olężałek, Racjonalny czy nieracjonalny ustawodawca? Uwagi na tle polskiego ustawodawstwa ze szczególnym uwzględnieniem prawa karnego sensu largo, w: O stabilność kodeksu karnego w świetle realiów. Ksiegga Jubileuszowa Profesora Stanisława Hoca, t. 2, red. D. Mucha, Wydawnictwo Scriptorium, Opole 2018, s. 93 i nast.

${ }^{11}$ W. Wróbel, Czy powrót do racjonalizmu? Projekty nowelizacji kodeksu karnego w perspektywie zmian dokonanych w prawie karnym $w$ latach 2005-2007, w: Populizm penalny i jego przejawy w Polsce, red. Z. Sienkiewicz, R. Kokot, Kolonia Limited, Wrocław 2009, s. 117.

${ }^{12}$ Ibidem, s. 104. 
prawa karnego nie ma na celu rzeczywistego ograniczania lub zapobiegania przestępczości, ale dostarczenie satysfakcji emocjonalnej (moralnej) jak najszerszej grupie społecznej, co w konsekwencji ma prowadzić do zwiększenia poparcia politycznego dla osób i środowisk proponujących daną zmianę normatywną. Populizm penalny to zespół społecznych przekonań, a także działań politycznych i legislacyjnych podejmowanych z programowym ograniczaniem roli ekspertów, współkształtowany przez media, charakteryzujący się surowym nastawieniem do przestępczości. Popełnienie przestępstwa traktuje się jako dowód na źle skonstruowane regulacje prawne. W efekcie projekt zmian prawa karnego ma na celu usunięcie domniemanego błędu, za który najczęściej uważa się zbyt niskie kary ${ }^{13}$.

Charakterystycznym dla populizmu penalnego rodzajem ustawodawstwa karnego jest tzw. prawo satysfakcji moralno(społeczno)-emocjonalnej. Polega to na wprowadzaniu nowych typów czynów zabronionych oraz zaostrzaniu odpowiedzialności karnej w reakcji na konkretne zdarzenia wywołujące emocje społeczne. Najczęściej zdarzenia te mają charakter wyjątkowy, a projekty zmian legislacyjnych pojawiają się, zanim jeszcze dojdzie do osądzenia sprawców przez sąd. Nowelizacja prawa karnego stanowi zatem swoiste symboliczne „ukaranie” popełnionego czynu przez ustawodawcę ${ }^{14}$.

Innym typem zmian populistycznych jest tworzenie tzw. prawa karnego wroga. Polega ono na obniżaniu standardów gwarancyjnych w zakresie prawa karnego wobec określonych grup sprawców, realizowanym pod hasłem: „prawomyślni obywatele nie mają się czego obawiać”. „Prawo karne wroga” potrafi zogniskować negatywne emocje społeczne przeciwko określonym grupom społecznym, czyniąc je odpowiedzialnymi za brak poczucia bezpieczeństwa czy nawet pewne trudności gospodarcze. W tej roli występują np. recydywiści, chuligani stadionowi, nietrzeźwi kierowcy, sprawcy przestępstw seksualnych, zwłaszcza pedofile, czy właśnie także sprawcy zorganizowanych przestępstw podatkowych określani mianem „mafii VAT-owskiej” czy „mafii paliwowej”. Tacy sprawcy stają się w pewnym sensie obywatelami drugiej kategorii - skoro świadomie decydują się złamać prawo, nie ma powodu, aby chronić ich w ten sam sposób jak innych (porządnych) obywateli ${ }^{15}$.

W tym, co zostało tutaj powiedziane, chodzi o pewne uogólnienia w zakresie charakterystyki głównych kierunków zmian w prawie karnym. To nie jest tak, że wszystkie zmiany normatywne podlegają negatywnej ocenie, bezdyskusyjne są np. te, które wynikają z zobowiązań międzynarodowych, zwłaszcza w obszarach takich jak: terroryzm, przepisy antykorupcyjne, ochrona danych informatycznych itp. Nikt też nie kwestionuje prawa, a także obowiązku ustawodawcy

13 Ibidem, s. 107.

14 Ibidem, s. 106-107.

15 Ibidem, s. 106. 
do ochrony ważnych dóbr społecznych, np. ochrony małoletnich przed różnego rodzaju czynami nieobyczajnymi czy pornografią. Powstaje tylko pytanie - dlaczego robi się to w taki sposób, jak to obrazuje historia zmian np. art. 200 k.k.? Co stoi na przeszkodzie kompleksowemu i stabilnemu uregulowaniu tej ochrony małoletnich, dlaczego kolejnymi nowelizacjami podnosi się zagrożenie karne, jeszcze innymi - wprowadza się nowe typizacje, jedne paragrafy się uchyla, inne przepisy dodaje itp.? Niepokojąca nie jest zatem sama zasada ochrony pewnych dóbr, ale sposób jej realizacji polegający m.in. na wielokrotnych zmianach tej samej regulacji, co ujawnia chaos legislacyjny, nerwowość ustawodawcy, uleganie naciskom pochodzącym z różnych środowisk opiniotwórczych itp. ${ }^{16}$.

Niestabilność prawa karnego jest tak daleko posunięta, że w doktrynie podkreśla się, iż w tej sytuacji nie da się już odbudować autorytetu i powagi stabilnego, skodyfikowanego prawa karnego ${ }^{17}$. Łatwość, z jaką można dokonywać kolejnych, wielokrotnych nowelizacji ustaw karnych, jest „zaraźliwa” i de facto nie ma barw partyjnych. Destabilizacja prawa ustawowego powoduje zakłócenia spójności i racjonalności prawa karnego jako systemu, narastanie kazuistyki, komplikowanie przepisów, trudności w dydaktyce prawa karnego, niechęć i dystansowanie się środowiska naukowego oraz przesunięcie punktu ciężkości na prawo sądowe, które staje się gwarantem jego racjonalności, ale realizowanej nieraz wbrew woli ustawodawcy, na zasadzie tzw. kreatywnej wykładni prawa ${ }^{18}$. Niektórzy autorzy wyraźnie odróżniają powody niestabilności prawa karnego od realiów, w jakich ono obecnie funkcjonuje. Analizując te realia społeczne, stawiają pesymistyczną tezę, iż owa niestabilność ustaw karnych funkcjonuje w takich warunkach, że nie ma ona już nawet większego znaczenia. Oznacza to, że w omawianym zakresie sytuacja jest tak zła, że niestabilność ustaw karnych stanowi już niestety relatywnie nieznaczący, a w każdym razie drugorzędny problem wobec społecznych realiów funkcjonowania prawa ${ }^{19}$.

Przedstawione uwagi, chociaż wypowiadane zasadniczo w odniesieniu do kodeksu karnego, mają znaczenie „ogólnokarne”, albowiem odnoszą się również do tzw. pozakodeksowego prawa karnego (powiązanego z częścią ogólną kodeksu karnego poprzez przepis art. 116 k.k.) oraz autonomicznej i specjalistycznej dziedziny prawa karnego, jaką jest prawo karne skarbowe skodyfikowane w her-

${ }^{16}$ Zob. L. Wilk, Prawo karne materialne - narastająca niestabilność. Przyczyny, kierunki i skutki nowelizacji, w: Problemy przeciwdziałania inflacji przepisów prawnych i poprawy ich jakości, red. L. Tyszkiewicz, J. Storczyński, Wydawnictwo Wyższej Szkoły Finansów i Prawa, Bielsko-Biała 2018, s. 41 i nast.

17 W. Wróbel, Czy powrót do racjonalizmu?..., s. 117.

${ }_{18}$ Ibidem; zob. także: S. Lelental, w: Populizm penalny..., s. 121; L. Wilk, Prawo karne materialne - narastająca niestabilność..., s. 55-56.

19 Zob. R. Zawłocki, O realiach niestabilnego Kodeksu karnego (dlaczego niestabilność Kodeksu karnego może nie mieć większego znaczenia), w: O stabilność kodeksu karnego w świetle realiów..., s. 291-298. 
metycznie zamkniętym kodeksie karnym skarbowym z 1999 r. Jest on poprzez ograniczoną zasadę recepcji powiązany z jednej strony z kodeksem karnym (art. 20 k.k.s. wymienia enumeratywnie te przepisy kodeksu karnego, które znajdują odpowiednie zastosowanie w kodeksie karnym skarbowym), z drugiej zaś poprzez blankietową technikę typizacji (polegającą na tym, że opis znamion zawarty w kodeksie karnym skarbowym wymaga uzupełnienia przepisami spoza tego kodeksu) - z prawem finansowym, gdzie aktywność ustawodawcy dopiero jest imponująca, zwłaszcza gdy chodzi o prawo podatkowe, w którym, jak pamięcią sięgnąć, trwa nieustanna jego reforma.

\section{Kierunki ewolucji kodeksu karnego skarbowego}

Patrząc z perspektywy czasu na kodeks karny skarbowy z 1999 r., można jak się wydaje - wyodrębnić w jego dwudziestoletniej historii dwa dziesięcioletnie okresy ${ }^{20}$. W obu można zaobserwować tendencję do rozszerzania zakresu kryminalizacji oraz zwiększania represyjności, jednak w drugim okresie tendencja ta rysuje się zdecydowanie wyraźniej. Obszerna nowelizacja kodeksu karnego skarbowego z $2005 \mathrm{r}^{21}$ podniosła m.in. górną granicę kary pozbawienia wolności z 3 do 5 lat, wydłużyła okresy przedawnienia karalności, wyłączyła sprawców kierowniczych i polecających z podmiotowego zakresu zastosowania instytucji czynnego żalu, zmieniła charakter nadzwyczajnego obostrzenia kary z fakultatywnego na obligatoryjny, wprowadziła także do części szczególnej nowe typy czynów zabronionych, np. art. 76a - typ oszustwa polegającego na narażeniu na nienależny zwrot wydatków związanych z budownictwem mieszkaniowym, art. 73a - zmiana przeznaczenia wyrobu akcyzowego, czy art. 80a - fałszowanie tzw. informacji podsumowującej. Tym niemniej ta nowelizacja wprowadziła również szereg zmian pozytywnie ocenianych w doktrynie, np. w zakresie odpowiedzialności posiłkowej czy w kwestii zracjonalizowania regulacji wyrażających priorytet egzekucji przed represją ${ }^{22}$.

${ }^{20}$ Po 10 latach obowiązywania k.k.s. 17 grudnia 2010 r. na Wydziale Prawa, Administracji i Ekonomii Uniwersytetu Wrocławskiego odbyła się konferencja naukowa pt. „10 lat Kodeksu karnego skarbowego - ocena i perspektywy zmian” z inicjatywy twórcy tego kodeksu - Profesora Zygfryda Siwika, której rezultatem jest monografia Kodeks karny skarbowy po dziesięciu latach obowiazywania - ocena i perspektywy zmian (Wydawnictwo Uniwersytetu Wrocławskiego, Wrocław 2010). Po kolejnych 10 latach takiej konferencji (o ile mi wiadomo) nie zorganizowano pytanie: czy tylko z powodu pandemii?

${ }^{21}$ Ustawa z 28 lipca 2005 r. o zmianie ustawy - Kodeks karny skarbowy oraz niektórych innych ustaw (Dz.U. z 2005 r., nr 178, poz. 1479).

22 Obszerna ocena zmian wprowadzonych tą nowelizacją zawarta jest w monografii pokonferencyjnej: Kodeks karny skarbowy po dziesięciu latach obowiązywania...; syntetyczna, krótka ocena w publikacji: L. Wilk, Założenia nowelizacji Kodeksu karnego skarbowego z 28.7.2005 r. (część materialnoprawna), „Monitor Prawniczy” 2006, nr 1, s. 7-16. 
Natomiast w drugim dziesięcioletnim - dotychczas - okresie obowiązywania kodeksu karnego skarbowego daje się wyraźnie zaobserwować kampanijny styl zwalczania przestępczości skarbowej. Pierwsza kampania skierowana została przeciwko przestępczości hazardowej i była rezultatem wejścia w życie bardzo restrykcyjnej ustawy z 19 listopada 2009 r. o grach hazardowych ${ }^{23}$, uchwalonej zresztą w szokującym wielu konstytucjonalistów trybie procedowania, charakterystycznym właśnie dla „kampanijnego” stylu zwalczania określonych zjawisk patologii społecznej. Hazard został poddany w kodeksie karnym skarbowym bardzo szerokiej kryminalizacji, naruszającej przy okazji standardy gwarancyjne prawa karnego ${ }^{24}$, a sprawę dodatkowo skomplikował - i osłabił przy tym praktyczną skuteczność represyjnego prawa - brak notyfikacji tzw. przepisów technicznych ustawy o grach hazardowych ${ }^{25}$. Gdy po kilku latach wraz ze stopniowym łagodzeniem restrykcji wspomnianej ustawy kampania przeciwko hazardowi zaczynała „przygasać”, w 2016 r. zainicjowano nową kampanię walki z przestępczością - tym razem podatkową, w szczególności z oszustwami w zakresie podatku VAT, realizowaną w ramach ogólnej akcji „uszczelniania systemu podatkowego". Trzeba przyznać, że gdy chodzi o patologie związane z podatkiem VAT, ustawodawca nie ograniczył się tylko do instrumentu represji karnej. Ustawą z 16 grudnia 2016 r. o zmianie ustawy o podatku od towarów i usług oraz niektórych innych ustaw ${ }^{26}$ wprowadzono m.in. modyfikacje sposobów rozliczeń i postępowań weryfikacyjnych oraz zmiany w zakresie mechanizmu tzw. odwróconego obciążenia VAT i odpowiedzialności solidarnej nabywcy za zaległości podatkowe podmiotu dokonującego dostaw określonych towarów.

\section{Nowelizacja kodeksu karnego skarbowego z 16 grudnia 2016 r.}

Gdy chodzi o kodeks karny skarbowy, nowelizacja z 16 grudnia 2016 r. wprowadziła zmiany zarówno w jego części ogólnej, jak i szczególnej. Wśród tych pierwszych na uznanie zasługuje zmiana treści art. $9 \$ 3$ k.k.s., który to przepis zawiera regulację zwaną „sprawstwem zastępczym” - chodzi tu o sytuację, gdy sprawca działa w cudzym imieniu i interesie. W orzecznictwie ukształtował się pogląd krytykowany przez niektórych autorów (w tym przez piszącego te słowa), tym niemniej dominujący, sprowadzający się w praktyce do tego, że czyny

23 Obecnie Dz.U. z 2018 r., poz. 165.

24 Zob. L. Wilk, Hazard. Studium kryminologiczne i prawne, C.H.Beck, Warszawa 2012, s. 175 i nast.

25 Zob. L. Wilk, Praktyczne aspekty i skutki nienotyfikowania przepisów technicznych dla sankcji administracyjnych i karnych, w: Skutki braku notyfikacji przepisów technicznych ustawy o grach hazardowych dla wymiaru sprawiedliwości Rzeczypospolitej Polskiej, red. M. Taborowski, Wolters Kluwer, Warszawa 2016, s. 226-238.

${ }^{26}$ Dz.U. z 2016 r., poz. 2024. 
wspólników spółki cywilnej realizujące znamiona typów czynów występujących w kodeksie karnym skarbowym, zwłaszcza powodujące uszczuplenia w zakresie podatków VAT i akcyzowego, pozostawały bezkarne, co z kryminalnopolitycznego punktu widzenia było zadziwiające ${ }^{27}$. Omawiana zmiana spowodowała możliwość pociągania także tych osób do odpowiedzialności karnoskarbowej na podstawie znowelizowanego przepisu art. $9 \$ 3$ k.k.s., czego od dawna domagała się praktyka. Ta praktyczna bezkarność wspólników spółek cywilnych trwała ok. 9 lat - tyle czasu potrzebował ustawodawca, aby zlikwidować tę zupełnie niezrozumiałą lukę, która wszakże de facto została w treści art. $9 \$ 3$ k.k.s. „wyłamana" przez orzecznictwo uznające, że jeżeli podatnikiem w myśl niektórych ustaw podatkowych może być spółka cywilna, to za przestępstwo lub wykroczenie skarbowe popełnione w jej imieniu i interesie nie może odpowiadać wspólnik, gdyż spółka cywilna nie posiada ogólnej zdolności prawnej, czego wymagał przepis art. $9 \$ 3$ k.k.s. Przez ten wymóg - zdaniem orzecznictwa - za przestępstwa i wykroczenia skarbowe popełnione w ramach działalności jednostek organizacyjnych niemających zdolności prawnej nikt praktycznie nie mógł odpowiadać karnie. Usunięcie wymogu posiadania zdolności prawnej przez jednostki organizacyjne umożliwiło pociąganie do odpowiedzialności karnej ich reprezentantów.

Nowelizacja z 16 grudnia 2016 r. znacząco zaostrzyła kary za wystawianie nierzetelnych faktur oraz posługiwanie się nimi z 240 do 720 stawek dziennych grzywny. Obok tej grzywny wprowadzono dodatkowo alternatywną karę pozbawienia wolności na czas nie krótszy od roku (zasadniczo do lat 5, ale z podwyższonymi restrykcjami w zakresie obligatoryjnego nadzwyczajnego obostrzenia kary) albo - jako kolejną alternatywę - wspomnianą grzywnę i pozbawienie wolności łącznie. Jest to w świetle systemu sankcji w kodeksie karnym skarbowym bardzo surowe zagrożenie.

W kontekście tej nowelizacji zwraca uwagę fakt, że ustawodawca, wypowiadając wojnę oszustwom VAT, nie zaostrzył kary za same oszustwa, ale za zachowania leżące „na przedpolu” oszustw, czyli za wystawianie nierzetelnych faktur VAT i obrót nimi. Odwraca to klasyczny układ proporcji, w którym to, co jest „na przedpolu”, zwykle karane jest łagodniej niż to, co jest już „docelowe”. To trochę tak, jak gdyby usiłowanie spotkania $z$ małoletnim w celu jego wykorzystania seksualnego było karane surowiej niż samo wykorzystanie, a przecież wiadomo, że jest inaczej, o czym przekonuje porównanie sankcji art. 200a $\$ 1$ oraz art. $200 \$ 1$ k.k. Takie odwrócenie klasycznego układu proporcji surowości represji - jak zauważa doktryna - pociąga za sobą także konsekwencje w zakresie stosowania reguł wyłączania wielości ocen, co dotyczy zwłaszcza zasady kon-

27 Zob. L. Wilk, w: L. Wilk, J. Zagrodnik, Kodeks karny skarbowy. Komentarz, wyd. IV, C.H.Beck, Warszawa 2018, s. 66-67. 
sumpcji ${ }^{28}$. Powoduje to bowiem wątpliwości co do tego, który czyn ma w końcu wyższą społeczną szkodliwość i powinien być czynem pochłaniającym - ten „na przedpolu", czy ten docelowy.

\section{Nowe typy tzw. przestępstw fakturowych w kodeksie karnym}

Zwraca również uwagę pośpiech ustawodawcy - nie zechciał on poczekać na efekty omawianej nowelizacji kodeksu karnego skarbowego zaostrzającej represje za skarbowe przestępstwa fakturowe, gdyż w dwa miesiące po uchwaleniu tej nowelizacji uchwalił z kolei ustawę z 10 lutego 2017 r. o zmianie ustawy - Kodeks karny oraz niektórych innych ustaw ${ }^{29}$. Wprowadziła ona do kodeksu karnego nowe typy tzw. fałszerstw fakturowych, zarówno materialnych (art. 270a), jak i intelektualnych (art. 271a) o charakterze lex specialis wobec istniejących już tam ogólnych typów fałszerstw dokumentów określonych w art. 270 i 271, w stosunku do których nowe typy fałszerstw fakturowych mają charakter typów kwalifikowanych. Są one zagrożone karami od 6 miesięcy do 8 lat pozbawienia wolności, natomiast gdy fałszywe faktury opiewają na wartości wyższe niż pięciokrotność kwoty określającej mienie wielkiej wartości albo gdy sprawca uczynił sobie z popełniania przestępstwa stałe źródło dochodu, fałszerstwa te są zbrodniami zagrożonymi karą pozbawienia wolności na czas nie krótszy od lat 3. Jeżeli fałszywe faktury opiewają na wartości wyższe niż dziesięciokrotność kwoty określającej mienie wielkiej wartości, fałszerstwa podlegają karze na czas nie krótszy od lat 5 albo karze 25 lat pozbawienia wolności. Ogólnie stwierdzić więc można, że wprowadzona do kodeksu karnego regulacja w zakresie tzw. przestępstw fakturowych cechuje się dużą kazuistyką i równie wielką surowością stopniowaną wraz ze wzrostem wartości, na jakie opiewają sfałszowane faktury (sięgającą 25 lat pozbawienia wolności), która to surowość jest korygowana przez niedookreśloną instytucję wypadku mniejszej wagi oraz instytucję czynnego żalu zawierającą warunki denuncjacji oraz zwrotu korzyści z przestępstwa. Oferowane jednak sprawcy spełniającemu te warunki dobrodziejstwa pozostają w znacznej mierze w swobodnym uznaniu prokuratura, w części zaś w równie swobodnym uznaniu sądu tak, że sprawca nie ma pewności skorzystania z nadzwyczajnego złagodzenia kary lub odstąpienia od jej wymierzenia, co osłabia działanie tych regulacji, nastawionych co do zasady na rozbicie solidarności członków zorganizowanych grup przestępczych oraz kompensowanie uszczerbku majątkowego Skarbu Państwa (zob. art. 277c).

${ }_{28}$ Zob. G. Łabuda, w: P. Kardas, G. Łabuda, T. Razowski, Kodeks karny skarbowy. Komentarz, Lex/el, Wolters Kluwer, Warszawa 2018, kom. do art. 62.

${ }^{29}$ Dz.U. z 2017 r., poz. 244. 
Uzasadnienie omówionej nowelizacji kodeksu karnego z 10 lutego 2017 r. ${ }^{30}$ może budzić zdziwienie. Projektodawcy utyskują w nim na nadmierny liberalizm kodeksu karnego skarbowego w kwestii fałszerstw faktur, nie zauważając, że na ten liberalizm ustawodawca znalazł już rozwiązanie poprzez dokonaną zaledwie 2 miesiące wcześniej nowelizację kodeksu karnego skarbowego z 16 grudnia 2016 r., która - jak wspomniano - drastycznie zaostrzyła kary za skarbowe fałszerstwa fakturowe. Uzasadnienie, o którym mowa, pomija natomiast argument działający w istocie na korzyść nowelizacji, do której się odnosi, mianowicie de facto kryminalny, a nie podatkowy charakter zorganizowanych procederów wyłudzania podatku VAT. Pomija też owo uzasadnienie kolejny argument na swoją korzyść, jakim było zbyt wąskie ujęcie w treści art. 271 k.k. kręgu podmiotów tego fałszerstwa intelektualnego dokumentu. Podmiotem takim jest $\mathrm{w}$ tym przepisie funkcjonariusz publiczny lub osoba uprawniona do wystawienia dokumentu, podczas gdy w doniosłej z kryminologicznego punktu widzenia grupie sprawców wystawiających „puste” faktury - tzw. słupów - podmioty te nie są uprawnione do wystawiania faktur VAT, zatem nie obejmował ich (niestety) art. $271 \mathrm{k.k}$. Z tego też powodu przyjęcie konstrukcji przestępstwa powszechnego („kto...”) w omawianej nowelizacji we wprowadzonym art. 271a k.k. zasługuje na uznanie. Wreszcie uzasadnienie omawianej nowelizacji kodeksu karnego zauważa możliwość zbiegu kwalifikacji prawnych tegoż kodeksu oraz kodeksu karnego skarbowego w odniesieniu do tego samego czynu i stwierdza, że zagadnienie tego typu zbiegu jest gruntownie omówione w literaturze oraz poddane analizie orzecznictwa. W ten sposób projektodawcy zmian w kodeksie karnym zręcznie pozbyli się problemu i pozostawili jego rozwiązanie orzecznictwu, które tak naprawdę w tej kwestii jednolite nie jest, wobec czego wiele wątpliwości interpretacyjnych dotyczących zbiegu przepisów kodeksów karnego i karnego skarbowego w zakresie fałszerstw, a także oszustw, pozostaje w istocie nierozstrzygniętych ${ }^{31}$.

\section{Projekt niedoszłej nowelizacji kodeksu karnego skarbowego z 21 grudnia 2018 r.}

Uszczelnienie systemu podatkowego będące hasłem przewodnim omówionych zmian w kodeksie karnym skarbowym i kodeksie karnym powróciło po raz kolejny w opracowanym przez Ministerstwo Sprawiedliwości projekcie ustawy o zmianie ustawy - Kodeks karny skarbowy z dnia 21 grudnia 2018 r. ${ }^{32}$. Projekt

${ }^{30}$ Zob. druk sejmowy Nr 888 Sejm RP VIII kadencji.

${ }_{31}$ Zob. L. Wilk, Kwalifikacje prawne przestępstw skarbowych $i$ wykroczeń skarbowych zwiqzanych $z$ obrotem fakturami i rachunkami..., s. 36-38.

${ }^{32}$ Został on zamieszczony na stronie Rządowego Centrum Legislacji w zakładce „Rządowy Proces Legislacyjny" pod numerem UD 188. 
tej nowelizacji objął ponad 70 propozycji zmian kodeksu karnego skarbowego, co, zważywszy na ogólną liczbę 191 przepisów tego kodeksu, świadczy o skali tej inicjatywy legislacyjnej. Wpisała się ona w szeroko zakrojoną $\mathrm{w}$ tym czasie ofensywę legislacyjną w sferze prawa karnego, znajdującą odzwierciedlenie $\mathrm{w}$ projektach istotnych zmian również w kodeksie karnym, kodeksie postępowania karnego oraz ustawie o odpowiedzialności podmiotów zbiorowych za czyny zabronione pod groźbą kary ${ }^{33}$. Projekt nowelizacji kodeksu karnego skarbowego podważył w istocie jedno z głównych założeń karnoskarbowej filozofii karania, jakim jest priorytet egzekucji przed represją. Przejawia się on w szeregu regulacji, których wspólnym elementem jest to, że odpowiednio wczesne wyrównanie uszczerbku finansowego wierzyciela daninowego wpływa na redukcję (złagodzenie) lub nawet wyłączenie odpowiedzialności karnoskarbowej. Zakładana zmiana $\mathrm{w}$ tej kwestii, w swej istocie fundamentalna, miała w projekcie charakter tak dyskretny, że ktoś nieobeznany w problematyce prawa karnego skarbowego mógłby jej w ogóle nie dostrzec. Polega ona mianowicie na wykreśleniu słowa: „wymagalna” („wymagalnej”), występującego w treści wielu regulacji kodeksu karnego skarbowego wyrażających $\mathrm{w}$ swym całokształcie wspomniany priorytet egzekucji przed represją. W rezultacie tego warunek uiszczenia w całości uszczuplonej należności publicznoprawnej miał dotyczyć także takiej należności, która nie jest już wymagalna, np. została przez organ podatkowy umorzona lub uległa przedawnieniu. Ciekawe, w jaki sposób organ ścigania (KAS) miał wytłumaczyć podatnikowi, który oszukał fiskusa, ale uzyskał decyzję organu podatkowego o umorzeniu zaległości lub też zaległość uległa przedawnieniu, że aby mógł skorzystać ze złagodzenia represji, musi jednak tę należność, choć już niewymagalną, uiścić? Czy można mówić o egzekucyjnej funkcji prawa karnego skarbowego, jeżeli chce się egzekwować to, czego wierzyciel daninowy sam się zrzekł? Egzekwowanie niewymagalnego nie jest przecież egzekucją, lecz represją.

$\mathrm{Z}$ taką propozycją nowelizacyjną współgrała kolejna, przewidująca usunięcie przepisu art. $44 \$ 2$ k.k.s., stanowiącego, że karalność przestępstwa skarbowego polegającego na uszczupleniu lub narażeniu na uszczuplenie należności publicznoprawnej ustaje także wówczas, gdy nastąpiło przedawnienie tej należności. Ta propozycja wyrażała $\mathrm{w}$ istocie zerwanie $\mathrm{z}$ założeniem subsydiarnej i racjonalnej ochrony karnoskarbowej istniejących (a nie nieistniejących) zobowiązań publicznoprawnych. Była to próba odzyskania za wszelką cenę, nawet wbrew

33 Projekt ustawy o odpowiedzialności podmiotów zbiorowych za czyny zabronione pod groźbą kary w wersji z dnia 21 grudnia 2018 r., https://legislacja.rel.gov.pl/docs/2/12312062/1251 1932/12511933/dokument374224.pdf [dostęp: 1.02.2019]; projekt ustawy o zmianie ustawy - Kodeks postępowania karnego oraz niektórych innych ustaw, Druk Sejmowy Nr 3251, http://orka. sejm.gov.pl/Druki8ka.nsf/dok?OpenAgent\&8-020-1246-2019 [dostęp: 1.02.2019]; projekt ustawy o zmianie ustawy - Kodeks karny oraz niektórych innych ustaw z dnia 25 stycznia 2019 r., https://legislacja.rel.gov.pl/docs//2/12320403/12565603/12565604/dokument378684.pdf [dostęp: 1.02.2019]. 
regulacjom prawa podatkowego dotyczącym przedawnienia uszczuplonej należności publicznoprawnej o charakterze ewidentnie represyjnym.

Przejawem tej samej tendencji była propozycja, aby dotychczasowe wykroczenie skarbowe określone w art. $57 \$ 1$ k.k.s., polegające na uporczywym niewpłacaniu w terminie podatku, uczynić przestępstwem skarbowym zagrożonym maksymalnie wysoką karą grzywny wówczas, gdy kwota podatku, od wpłacenia którego podatnik „uporczywie” się uchyla, przekraczałaby pięćdziesięciokrotność minimalnego wynagrodzenia.

Omawiany projekt nowelizacji kodeksu karnego skarbowego proponował także zaostrzenie do maksymalnie możliwej wysokości kar pozbawienia wolności za m.in. takie przestępstwa podatkowe, jak: obrót wyrobami akcyzowymi bez znaków skarbowych akcyzy (art. 63), umyślne paserstwo akcyzowe (art. 65 $\$ 1$ ) czy produkcja i magazynowanie wyrobów akcyzowych poza składem podatkowym (art. 69a).

Kiedy w końcu marca 2019 r. wraz z Jarosławem Zagrodnikiem oddawaliśmy do druku książkę pt. Prawo i proces karny skarbowy, która ukazała się w Wydawnictwie C.H.Beck ${ }^{34}$, obserwacja tempa i sposobu procedowania wspomnianego projektu nowelizacji kodeksu karnego skarbowego, determinacji rządzących we wprowadzaniu zmian oraz „matematyki” parlamentarnej skłoniła Wydawnictwo i nas - autorów - do wniosku, że wysokie jest prawdopodobieństwo, że ów projekt stanie się wkrótce obowiązującym prawem. Dlatego też uwzględniliśmy go w treści tej publikacji.

Nasza ocena „rozpędzonej machiny legislacyjnej” okazała się w tym przypadku błędna - z niezrozumiałych dla osób spoza kręgów polityki powodów rządzące ugrupowanie nie uchwaliło tej zmiany przed wyborami parlamentarnymi z 2019 r., a po nich do niej nie powróciło. Podobnie zresztą stało się z projektem nowelizacji kodeksu karnego.

\section{Najnowsze zmiany w kodeksie karnym skarbowym (2018-2021)}

Omówiony projekt nowelizacji kodeksu karnego skarbowego, zasługujący ze względu na swoją skalę na miano przynajmniej częściowej rekodyfikacji, który nie stał się obowiązującym prawem, po pierwsze, odzwierciedla tendencje w polityce kryminalnej wobec przestępczości podatkowej, po drugie, nie zatrzymał dalszych, już cząstkowych (można powiedzieć - „punktowych”) zmian w tym kodeksie.

Biorąc pod uwagę - jako współautor cyklicznie wydawanego komentarza do kodeksu karnego skarbowego - dwuletni okres (2018-2020), jaki upłynął

${ }^{34}$ L. Wilk, J. Zagrodnik, Prawo i proces karny skarbowy, C.H.Beck, Warszawa 2019. 
od czwartego wydania tego komentarza ${ }^{35}$ do wydania piątego, już z roku 2021, zauważyłem pojawienie się w tym czasie w części szczególnej kodeksu karnego skarbowego dziesięciu nowych jednostek artykułowych (wszystkie w rozdziale 6 - „podatkowym”) - wprowadzających nowe typizacje, niekiedy bardzo rozbudowane (np. nowy art. 80f wprowadził osiem typów czynów zabronionych). Nie powrócono natomiast do propozycji zawartych we wspomnianym wcześniej projekcie obszernej nowelizacji kodeksu karnego skarbowego z 21 grudnia 2018 r., którego procedowanie zakończono bez rezultatu. Zatem w okresie 2018-2020 obserwowaną tendencją w polityce kryminalnej wobec przestępczości podatkowej jest rozszerzenie zakresu kryminalizacji, albowiem do wspomnianych dziesięciu nowych, w tym wieloparagrafowych, artykułów w rozdziale 6 („podatkowym”) należy dodać zmiany $\mathrm{w}$ niektórych typizacjach już istniejących, polegające na dołączeniu pewnych znamion, przez co w efekcie zakres kryminalizacji się rozszerza $^{36}$. Ostatnim przejawem tego rozszerzania objętym ramami niniejszego opracowania jest art. 56e k.k.s., który obowiązuje od 1 stycznia $2021 \mathrm{r}$.

Zdecydowana większość tych najnowszych zmian polega na objęciu kryminalizacją niedopełnienia lub niewłaściwego wypełnienia kolejnych obowiązków tzw. informacyjnych - chodzi zatem o czyny formalne (bezskutkowe), niepowodujące bezpośrednio żadnego uszczuplenia ani narażenia podatku na uszczuplenie (czyli - według ustawowej definicji - spowodowania wysokiego prawdopodobieństwa uszczuplenia) $)^{37}$, lecz typy, które w karnistycznej doktrynie określane są mianem tzw. narażenia abstrakcyjnego ${ }^{38}$.

Jest także jeden nowy typ czynu karalnego, również o charakterze formalnym, z tzw. narażenia abstrakcyjnego, niepolegający jednak na niedopełnieniu jakiegoś obowiązku informacyjnego, lecz na dokonaniu płatności za towar lub usługę z pominięciem tzw. mechanizmu podzielonej płatności ${ }^{39}$. W istocie rzeczy jest to przejaw kryminalizacji tzw. przedpola oszustw karuzelowych w zakresie podatku VAT i w moim przekonaniu ta kryminalizacja zasługuje na pozytywną ocenę z punktu widzenia prewencji wspomnianych „karuzel”. Krótko mówiąc, mechanizm podzielonej płatności (split payment) został wprowadzony na gruncie podatku VAT z dniem 1 lipca 2018 r. (zob. art. 108a ustawy VAT). Polega on na tym, że płatność za towar lub usługę zostaje - jak wskazuje nazwa tego mechanizmu - podzielona na dwie części: wartość netto płacona jest na rachunek bankowy dostawcy towaru lub usługi, natomiast kwota podatku na specjalne konto dostawcy - rachunek VAT. Ten ostatni służy zasadniczo do regulowania

${ }^{35}$ L. Wilk, J. Zagrodnik, Kodeks karny skarbowy...

${ }^{36} \mathrm{~Np}$. art. $56 \S 4$ czy art. $56 \mathrm{~b} \$ 2$.

37 Zob. art. $53 \S 28$ k.k.s.

${ }^{38}$ Niebezpieczeństwo nie jest w nich elementem opisu czynu zabronionego i nawet gdyby in concreto żadne niebezpieczeństwo dla dobra prawnego nie występowało, sprawca ponosi odpowiedzialność karnoskarbową.

${ }^{39}$ Art. 57c k.k.s. 
zobowiązań podatkowych z tytułu podatku VAT lub do dokonywania przelewów na inny rachunek VAT. Oznacza to, że mechanizm podzielonej płatności ogranicza swobodę dysponowania podatkiem VAT przez dostawcę towaru lub usługi i tym samym przeciwdziała zjawisku pobierania zapłaty za towar lub usługe wraz z należnym podatkiem VAT, a następnie nieprzekazywania tego podatku organom skarbowym. Eliminuje zatem ryzyko „znikania” podatników (modus operandi tzw. karuzel VAT-owskich zawiera m.in. właśnie pojęcie „znikającego podatnika", który czyni to, na co wskazuje jego nazwa) wraz z zapłaconym im przez kontrahentów i nieodprowadzonym do fiskusa podatkiem VAT, co odbywa się w ramach tzw. oszustw karuzelowych ${ }^{40}$.

Innym nowo kryminalizowanym zachowaniem, które wyjątkowo na tle pozostałych nie polega na niedopełnieniu obowiązków informacyjnych, jest to, które zostało określone $\mathrm{w}$ art. 57a k.k.s. Przepis ten grozi komornikom sądowym występującym tu w charakterze podmiotu czynu indywidualnego karą za nieprzekazanie do budżetu państwa uzyskanych opłat egzekucyjnych. Kara ta jest - jak na kodeks karny skarbowy - maksymalnie wysoka, tj. do 720 stawek dziennych grzywny albo kara pozbawienia wolności (do 5 lat) lub obie te kary łącznie, chyba że czyn zostanie uznany za tzw. wypadek mniejszej wagi - wówczas jako wykroczenie skarbowe podlega tylko karze grzywny.

Spośród wprowadzonych w ostatnim okresie (2018-2021) nowych typów czynów „podatkowych” polegających na niedopełnieniu lub niewłaściwym wypełnieniu różnych obowiązków informacyjnych zwraca uwagę bardzo obszerna (pięcioparagrafowa) regulacja art. 80f k.k.s. obejmująca - jak już wspomniano osiem typów czynów zabronionych.

Ich istota sprowadza się zasadniczo do naruszenia obowiązków w zakresie raportowania o tzw. schematach podatkowych. Schematy podatkowe oraz związane $\mathrm{z}$ nimi obowiązki raportowania stanowią całkowicie nową instytucję polskiego prawa podatkowego. Chociaż schemat podatkowy jest pojęciem w istocie szerszym od tego, co na gruncie podatków określa się mianem agresywnej optymalizacji podatkowe ${ }^{41}$, to $\mathrm{w}$ istocie regulacje dotyczące raportowania o schematach podatkowych nakierowane są zwłaszcza na umożliwienie szybkiego dostępu administracji skarbowej do informacji o potencjalnie agresywnej optymalizacji podatkowej oraz podmiotach korzystających ze schematów podatkowych. Przepisy te powinny zniechęcić podatników oraz ich doradców do wdrażania u podatników uzgodnień mogących stanowić agresywną optymalizację podatkową (według terminologii ustawy - Ordynacja podatkowa - unikanie opodatkowania). W praktyce może wystąpić sytuacja, że zaraportowany schemat podatkowy nie będzie miał dla podatnika żadnych negatywnych konsekwencji, tym niemniej

${ }^{40}$ G. Skowronek, Kodeks karny skarbowy. Komentarz, C.H.Beck, Warszawa 2020, s. 178-179.

${ }^{41}$ Zob. np. K. Hanuszek, Agresywna optymalizacja podatkowa - pojęcie, regulacja, praktyka, w: Agresywna optymalizacja podatkowa - problem podatnika czy problem państwa?, red. J. Glumińska-Pawlic, Wydawnictwo Uniwersytetu Śląskiego, Katowice 2017, s. 76 i nast. 
Szef KAS chce zachować możliwość samodzielnej oceny, czy w danych czynnościach mających lub mogących mieć wpływ na powstanie lub niepowstanie obowiązku podatkowego występują elementy charakterystyczne dla agresywnej optymalizacji podatkowej, w szczególności element „sztuczności”.

Osiem karalnych zachowań stypizowanych w obrębie art. 80f k.k.s. ma więc na celu wspomóc dzięki sankcji karnej działanie tych norm prawa podatkowego, które mają umożliwić organom skarbowym identyfikację zachowań nazywanych agresywną optymalizacją podatkową. Jest ona zjawiskiem bardzo niepokojącym organy fiskalne i ustawodawców wielu państw. Stanowi przedmiot regulacji unijnych $\mathrm{w}$ odniesieniu do uzgodnień (czyli schematów) transgranicznych ${ }^{42}$ oraz przedmiot ingerencji ustawodawstw krajowych.

Należy sobie uświadomić, że o ile tzw. ciemna liczba przestępstw podatkowych, a więc zachowań nielegalnych, karalnych, mających na celu redukcję zobowiązań podatkowych, jest prawdopodobnie bardzo wysoka, o tyle zjawisko zwane ogólnie optymalizacją podatkową jest już nagminne. Dążenie do wyeliminowania, a przynajmniej pomniejszenia obciążeń podatkowych, mające różnorodne uwarunkowania, samo w sobie uznawane jest powszechnie za naturalne i nienaganne $e^{43}$.

Nie ma przecież ani w naszym ustawodawstwie, ani w żadnym innym reguły nakazującej płacić najwyższe możliwe podatki. Tak więc dążenie do zmniejszenia swoich obciążeń podatkowych uważane jest za zupełnie normalne i zasadniczo korzysta z ochrony prawnej streszczanej nawet jako zasada wolności unikania opodatkowania. Natomiast odbiegające od normy byłoby zachowanie przeciwne, polegające na tym, że strony różnych czynności cywilnoprawnych, gospodarczych regulowałyby swoje stosunki majątkowe w sposób maksymalnie korzystny dla fiskusa, a niekorzystny dla siebie.

Jest jednak również oczywiste, że ta wolność wyboru drogi najmniej opodatkowanej w pewnym miejscu zderza się z potrzebą ochrony interesów fiskalnych państwa, a także z zasadą równości opodatkowania, wobec czego ta wolność, jak każda inna, musi mieć pewne granice, poza którymi określone zachowania powodują już uruchomienie norm pozwalających na zniweczenie ich skutków podatkowych korzystnych dla podatnika i odzyskanie przez państwo utraconego podatku. Problemem dla ustawodawców jest zwłaszcza tzw. agresywna optymalizacja podatkowa. Doktryna formułuje różne kryteria odróżnienia jej od optymalizacji nieagresywnej ${ }^{44}$. W wielkim uproszczeniu można powiedzieć, że o ile w optymalizacji nieagresywnej czynnościom mającym cel gospodarczy, dokonywanym przez podatnika, towarzyszy dążenie do zminimalizowania obciążeń

${ }^{42}$ Zob. Dyrektywę Rady Unii Europejskiej z 2016/1164 o przeciwdziałaniu unikaniu opodatkowania - Dz.Urz.UE L 193 z 19 lipca 2016 r., s. 1.

${ }^{43}$ Zob. np. P. Karwat, Obejście prawa podatkowego, „Przegląd Podatkowy” 2003, nr 2, s. 48 i nast.

${ }^{44}$ Zob. K. Hanuszek, Agresywna optymalizacja podatkowa..., s. 76. 
podatkowych, o tyle w przypadku optymalizacji agresywnej działania podejmowane w jej ramach (rozporządzanie majątkiem, przekształcenia struktur gospodarczych itp.) mają służyć wyłącznie lub przede wszystkim uniknięciu lub przynajmniej zminimalizowaniu obciążeń podatkowych.

Niezwykle trudne jest skonstruowanie ogólnej regulacji prawnej przeciwko agresywnej optymalizacji podatkowej wykorzystującej zasadę swobody umów w taki sposób, aby odpowiadała ona współczesnym standardom przyzwoitej legislacji podatkowej (z wyraźnymi analogiami do standardów legislacji karnej), w szczególności, aby uniknąć zarzutu redukcji stopnia pewności prawa dla obywatela niemal do zera.

Pierwsza taka próba wprowadzenia do Ordynacji podatkowej klauzuli przeciwko agresywnej optymalizacji podatkowej miała miejsce w 2003 r. ${ }^{45}$. Zakończyła się ona dyskwalifikacją tej klauzuli przez Trybunał Konstytucyjny ${ }^{46}$. Od tamtego czasu zastanawiałem się, czy i kiedy ustawodawca ponowi taką próbę. Uczynił to w 2016 r. $^{47}$, wprowadzając do Ordynacji podatkowej nowy Dział IIIA zatytułowany: Przeciwdziałanie unikaniu opodatkowania - owo „unikanie opodatkowania" to pojęcie, którym posłużył się ustawodawca w odniesieniu do tego, co doktryna nazywa agresywną optymalizacją podatkową. Tym razem - jak dotychczas - Trybunał Konstytucyjny nie zakwestionował tej regulacji. Powstaje pytanie - czy ustawodawca nie pokusi się o obwarowanie omawianej klauzuli sankcją karną? Mam nadzieję, że zdaje sobie (ustawodawca) sprawę, że ewentualne stypizowanie „przestępstwa agresywnej optymalizacji podatkowej” jawi się jako absolutnie niemożliwe.

Opis zachowań kwalifikowanych jako „unikanie opodatkowania” w Dziale IIIA Ordynacji podatkowej jest bardzo kazuistyczny i posługuje się tak dalece niedookreślonymi pojęciami, jak: „sztuczny sposób działania”, „działanie rozsądne”, „brak uzasadnienia ekonomicznego lub gospodarczego”, „nieuzasadnione dzielenie operacji”, „sprzeczność z przedmiotem i celem ustawy podatkowej” itp. W świetle gwarancyjnych standardów prawa karnego użycie tego rodzaju określeń w charakterze znamion czynu zabronionego bezwzględnie dyskwalifikowałoby taką typizację karną. Niedawno miałem przyjemność recenzowania interesującej i wartościowej rozprawy doktorskiej ${ }^{48}$, w której problem badawczy sprowadzał się do pytania - czy opisane w Dziale IIIA Ordynacji podatkowej zachowania określone mianem agresywnej optymalizacji podatkowej (a przez ustawodawcę nazywane unikaniem opodatkowania) mogą de lege lata (w świetle obecnej treści kodeksu karnego skarbowego) lub mogłyby de lege fe-

${ }^{45}$ Był to art. 24b Ordynacji podatkowej.

${ }^{46}$ Zob. wyrok TK z 11 maja 2004 K 4/03 (Dz.U. z 2004 r., nr 122, poz. 1288).

47 Chodzi o nowelizację Ordynacji podatkowej z 13 maja 2016 r. (Dz.U. z 2016 r., poz. 846).

${ }_{48}$ T. Budrewicz, Zagadnienie penalizacji agresywnej optymalizacji podatkowej $w$ doktrynie i orzecznictwie, rozprawa doktorska obroniona 13 października 2020 r. na Uniwersytecie SWPS w Warszawie. 
renda (w ramach ewentualnej kryminalizacji) rodzić odpowiedzialność karnoskarbową? Na to pytanie autor udzielił odpowiedzi kategorycznie negatywnej, z czym w pełni się zgadzam.

W tym stanie rzeczy kryminalizacja ośmiu zachowań polegających na niedopełnieniu lub niewłaściwym wykonaniu obowiązków raportowania schematów podatkowych wyczerpuje możliwości użycia represji karnej wobec zjawiska agresywnej optymalizacji podatkowej na dalekim jej „przedpolu”. Z tym zjawiskiem nie sposób walczyć za pomocą represji karnej.

\section{Niektóre okoliczności wyłączające karalność jako przykłady błędów w polityce kryminalnej}

Niniejsze opracowanie poświęcone obserwowanym tendencjom $\mathrm{w}$ polityce kryminalnej wobec przestępczości podatkowej zakończę uwagą, że ustawodawca od 15 już lat konsekwentnie utrzymuje w kodeksie karnym skarbowym regulację art. 16a, sprowadzającą się do tego, że gwarantuje on sprawcom oszustw podatkowych (ponieważ tylko do nich się odnosi) możliwość skutecznego i wyłączającego całkowicie karalność czynnego żalu nawet po ujawnieniu oszustwa przez organ kontroli państwowej, w świetle czego oszust podatkowy wie, że w razie „wpadki” i tak uniknie wszelkich karnych konsekwencji, o ile tylko spłaci zaraz kwotę uszczuplonego podatku. Tę regulację, sprawiającą wrażenie zachęty do dokonywania oszustw podatkowych („przecież wszystkich nie skontrolują"), krytykuję od początku jej powstania ${ }^{49}$, gdyż z kryminalnopolitycznego punktu widzenia jest ona nieuzasadniona przy stosowanym w naszym systemie podatkowym samowymiarze podatków i ograniczonych możliwościach aparatu kontrolnego.

Ustawodawca nie tylko nie usunął ani racjonalnie nie zmodyfikował przepisu art. 16a k.k.s., ale ustawą z 9 lutego 2017 r. o zmianie ustawy o podatku dochodowym od osób fizycznych oraz ustawy - Kodeks karny skarbowy ${ }^{50}$ dodał po art. 16a kolejny przepis - art. 16b, stanowiący, że nie podlega karze za przestępstwo lub wykroczenie skarbowe podatnik, który złożył zeznanie, o którym mowa we wskazanym tam przepisie ustawy o podatku dochodowym od osób fizycznych, w przypadku gdy zawiera ono błędy lub oczywiste omyłki powstałe $\mathrm{z}$ winy organu podatkowego (!) lub podatnika. Oczywiście doktryna karnoskarbowa od razu zauważyła, że przepis ten, najpewniej z powodu braku elementarnej wiedzy o zasadach odpowiedzialności karnoskarbowej u tych, którzy go przygotowali i uchwalili, trafia w próżnię ${ }^{51}$. Trudno zatem mówić, aby

\footnotetext{
${ }^{49}$ L. Wilk, Szczególne cechy odpowiedzialności..., s. 514-515.

${ }^{50}$ Dz.U. z 2017 r., poz. 528.

${ }^{51}$ Zob. P. Kardas, G. Łabuda, T. Razowski, Kodeks karny skarbowy..., kom. do art. $16 \mathrm{~b}$.
} 
realizował on jakąkolwiek funkcję kryminalnopolityczną wobec przestępczości podatkowej.

\section{Podsumowanie}

Podsumowując aktualne tendencje w polityce kryminalnej wobec przestępczości podatkowej, należy skonstatować, że zasadniczo sprowadzają się one do rozszerzania zakresu kazuistycznej kryminalizacji oraz zaostrzania penalizacji, przy czym zmiany te koncentrują się na tzw. przedpolu oszustw podatkowych. Odpowiada to ogólnym tendencjom polityki kryminalnej odzwierciedlającym traktowanie represji karnej nie jako ostatecznego, lecz priorytetowego środka zwalczania przestępczości. Ponieważ takie motywowane populistycznie podejście nie ma barw partyjnych, trudno prognozować realnie jakąś istotną zmianę w polityce kryminalnej. Przeciwnie - gospodarczo-społeczne skutki obecnej pandemii, oddziałujące $\mathrm{z}$ jednej strony niekorzystnie na budżet państwa, $\mathrm{z}$ drugiej zaś kryminogennie na przestępczość podatkową, mogą popychać polityków - czy to pragnących utrzymać władzę, czy to chcących ją zdobyć - do forsowania nieracjonalnych z kryminalnopolitycznego punktu widzenia rozwiązań. Obawiam się zwłaszcza o te konstrukcje kodeksu karnego skarbowego, które w obecnym kształcie wyrażają (na razie) racjonalną zasadę priorytetu egzekucji przed represją. Odwrócenie tego priorytetu i przestawienie akcentu na represję (co już sygnalizowała niedoszła nowelizacja kodeksu karnego skarbowego z 2018 r.) miałoby fatalne skutki dla budżetu, albowiem wpływy z kar majątkowych nie zrekompensują strat powodowanych przez przestępstwa podatkowe.

\section{Bibliografia}

Budrewicz T., Zagadnienie penalizacji agresywnej optymalizacji podatkowej $w$ doktrynie $i$ orzecznictwie, rozprawa doktorska obroniona 13 października 2020 r. na Uniwersytecie SWPS w Warszawie.

Hanuszek K., Agresywna optymalizacja podatkowa - pojęcie, regulacja, praktyka, w: Agresywna optymalizacja podatkowa - problem podatnika czy problem państwa?, red. J. Glumińska-Pawlic, Wydawnictwo Uniwersytetu Śląskiego, Katowice 2017, s. 76-90.

Kardas P., Łabuda G., Razowski T., Kodeks karny skarbowy. Komentarz, Lex/el, Wolters Kluwer, Warszawa 2018.

Karwat P., Obejście prawa podatkowego, „Przegląd Podatkowy” 2003, nr 2, s. 48-56.

Kodeks karny skarbowy po dziesięciu latach obowiąywania - ocena i perspektywy zmian, red. Z. Siwik, Wydawnictwo Uniwersytetu Wrocławskiego, Wrocław 2010.

Lernell L., Współczesne zagadnienia polityki kryminalnej. Problemy kryminogenne i penologiczne, Wydawnictwo Prawnicze, Warszawa 1978. 
Olężałek M., Racjonalny czy nieracjonalny ustawodawca? Uwagi na tle polskiego ustawodawstwa ze szczególnym uwzględnieniem prawa karnego sensu largo, w: O stabilność kodeksu karnego w świetle realiów. Księga Jubileuszowa Profesora Stanisława Hoca, t. 2, red. D. Mucha, Wydawnictwo Scriptorium, Opole 2018, s. 93-105.

Populizm penalny $i$ jego przejawy $w$ Polsce, red. Z. Sienkiewicz, R. Kokot, Kolonia Limited, Wrocław 2009.

Postanowienie SN z 1 marca 2004 V KK 248/03 Legalis.

Postanowienie SN z 10 lipca 2013 II KK 20/13 Legalis.

Prawo karne. Część ogólna, szczególna i wojskowa, red. T. Dukiet-Nagórska, O. Sitarz, Wolters Kluwer, Warszawa 2020.

Skowronek G., Kodeks karny skarbowy. Komentarz, C.H.Beck, Warszawa 2020.

System Prawa Karnego, t. 1, Zagadnienia ogólne, red. A. Marek, C.H.Beck, Warszawa 2010.

Tyszkiewicz L., Kryminologia, Wydawnictwo Uniwersytetu Śląskiego, Katowice 1983.

Tyszkiewicz L., Od naturalizmu do humanizmu w kryminologii, Wydawnictwo Uniwersytetu Śląskiego, Katowice 1992.

Wilk L., Hazard. Studium kryminologiczne i prawne, C.H.Beck, Warszawa 2012.

Wilk L., „Kryminalne” aspekty przestępczości podatkowej, „Archiwum Kryminologii” 2009, t. 31, s. 209-222.

Wilk L., Kwalifikacje prawne przestępstw skarbowych i wykroczeń skarbowych zwiazanych $z$ obrotem fakturami i rachunkami, w: Problematyka obrotu fakturami wystawionymi w sposób nierzetelny. Zagadnienia prawa karnego materialnego i procesowego, red. S. Kowalski, H. Paluszkiewicz, O. Włodkowski, C.H.Beck, Warszawa 2019, s. $25-38$.

Wilk L., Praktyczne aspekty i skutki nienotyfikowania przepisów technicznych dla sankcji administracyjnych i karnych, w: Skutki braku notyfikacji przepisów technicznych ustawy o grach hazardowych dla wymiaru sprawiedliwości Rzeczypospolitej Polskiej, red. M. Taborowski, Wolters Kluwer, Warszawa 2016, s. 226-239.

Wilk L., Prawo karne materialne - narastająca niestabilność. Przyczyny, kierunki i skutki nowelizacji, w: Problemy przeciwdziałania inflacji przepisów prawnych i poprawy ich jakości, red. L. Tyszkiewicz, J. Storczyński, Wydawnictwo Wyższej Szkoły Finansów i Prawa, Bielsko-Biała 2018, s. 41-56.

Wilk L., Szczególne cechy odpowiedzialności za przestępstwa i wykroczenia podatkowe, Wydawnictwo Uniwersytetu Śląskiego, Katowice 2006.

Wilk L., Założenia nowelizacji Kodeksu karnego skarbowego z 28.7.2005 r. (część materialnoprawna), „Monitor Prawniczy” 2006, nr 1, s. 7-16.

Wilk L., Zagrodnik J., Kodeks karny skarbowy. Komentarz, wyd. IV, C.H.Beck, Warszawa 2018.

Wilk L., Zagrodnik J., Prawo i proces karny skarbowy, C.H.Beck, Warszawa 2019.

Wróbel W., Czy powrót do racjonalizmu? Projekty nowelizacji kodeksu karnego w perspektywie zmian dokonanych $w$ prawie karnym w latach 2005-2007, w: Populizm penalny $i$ jego przejawy w Polsce, red. Z. Sienkiewicz, R. Kokot, Kolonia Limited, Wrocław 2009, s. 103-118.

Wyrok TK z 11 maja 2004 K 4/03 (Dz.U. z 2004 r., nr 122, poz. 1288). 
Zawłocki R., O realiach niestabilnego Kodeksu karnego (dlaczego niestabilność Kodeksu karnego może nie mieć większego znaczenia), w: O stabilność kodeksu karnego $w$ świetle realiów. Księga Jubileuszowa Profesora Stanisława Hoca, t. 2, red. D. Mucha, Wydawnictwo Scriptorium, Opole 2018, s. 291-298.

prof. dr hab. LESZEK WILK

e-mail: leszekwilk.us@gmail.com

Profesor w Wyższej Szkole Finansów i Prawa w Bielsku-Białej. Specjalizuje się w problematyce prawa karnego skarbowego, prawa karnego gospodarczego i kryminologii. Autor licznych publikacji naukowych i ekspertyz legislacyjnych. Radca prawny.

Author is a professor at Bielsko-Biala School of Finance and Law. Professor's Leszek Wilk research interests are concentrated on fiscal penal law, penal commercial law and criminology. He is an author of many scientific researches and legislative expertises. Legal counsel. 